\title{
Inhibition of histamine receptor 3 suppresses glioblastoma tumor growth, invasion, and epithelial-to-mesenchymal transition
}

\author{
Jia-Ji Lin ${ }^{1, *}$, Tian-Zhi Zhao ${ }^{2, *}$, Wen-Ke Cai, ${ }^{3,}$, Yong-Xiang Yang ${ }^{1}$, Chao Sun ${ }^{1}$, \\ Zhuo Zhang ${ }^{1}$, Yu-Qiao Xu ${ }^{4}$, Ting Chang ${ }^{1}$, Zhu-Yi Li ${ }^{1}$ \\ ${ }^{1}$ Department of Neurology, Tangdu Hospital, The Fourth Military Medical University, Xi'an, China \\ ${ }^{2}$ Department of Neurosurgery, Tangdu Hospital, The Fourth Military Medical University, Xi'an, China \\ ${ }^{3}$ Department of Cardio-Thoracic Surgery, Kunming General Hospital of Chengdu Military Region, Kunming, China \\ ${ }^{4}$ Department of Pathology, The Fourth Military Medical University, Xi'an, China \\ *These authors have contributed equally to this work \\ Correspondence to: \\ Zhu-Yi Li, e-mail: lizhuyi126@126.com \\ Ting Chang, e-mail: tdchangting126@126.com \\ Keywords: histamine receptor 3, glioblastoma, epithelial-to-mesenchymal transition, invasion \\ Received: January 25, $2015 \quad$ Accepted: March 24, $2015 \quad$ Published: April 10, 2015
}

\section{ABSTRACT}

Histamine receptor 3 (H3R) is expressed in various tumors and correlated with malignancy and tumor proliferation. However, the role of H3R in tumor invasion and epithelial to mesenchymal transition (EMT) remains unknown. Here, we explored the H3R in the highly invasive glioblastoma (GBM) and U87MG cells. We found that H3R mRNA and protein levels were up-regulated in the GBM and glioma cell lines compared to normal brain tissue and astrocytes. In U87MG cell line, inhibition of H3R by siRNA or the antagonist ciproxifan (CPX) suppressed proliferation, invasiveness, and the expression of EMT activators (Snail, Slug and Twist). In addition, expression of epithelial markers (E-cadherin and ZO-1) was up-regulated and expression of mesenchymal markers (vimentin and $\mathrm{N}$-cadherin) was down-regulated in vitro and in vivo in a xenograft model. In addition, we also showed that inhibition of H3R by siRNA or CPX inactivated the PI3K/Akt and MEK/ERK signaling pathways, while inhibition of Akt or ERK activity with antagonists or siRNAs suppressed H3R agonist $(R)-(a)-(-)-$ methylhistamine dihydrobromide (RAMH) mediated invasion and reorganization of cadherin-household. In conclusion, overexpression of H3R is associated with glioma progression. Inhibition of H3R leads to suppressed invasion and EMT of GBM by inactivating the PI3K/Akt and MEK/ERK pathways in gliomas.

\section{INTRODUCTION}

Diffuse infiltration of tumor cells in the brain is a central hallmark of high-grade astrocytomas, especially glioblastoma (GBM) [1,2]. Tumor invasiveness leads to severe structural and functional damage to the surrounding brain tissue, incomplete surgical resection and high frequency of tumor recurrence with a median survival time of 12-14 months $[1,2]$. One important factor that contributes to the invasiveness of high-grade astrocytomas is the epithelial to mesenchymal transition (EMT) of the glioma cells [3]. EMT is a complex cellular process reflecting a high level of phenotypic plasticity, which is marked by the down-regulation of epithelial markers (E-cadherin and ZO-1) and transcriptional induction of mesenchymal markers (vimentin and N-cadherin) [4]. The transition of epithelial cells to mesenchymal cells induces the loss of cell-cell adhesion, cell polarity, and the acquisition of migratory and invasive properties [3]. Understanding the mechanisms that drive EMT is therefore important to identify new targets for the prevention of metastasis in astrocytoma.

Compared with the other three histamine receptors subtypes, histamine receptor $3(\mathrm{H} 3 \mathrm{R})$ is mostly expressed 
in neurons, in which regulates the synthesis and release of histamine and neurotransmitters as presynaptic autoreceptors and heteroreceptors [5-8]. Although it is widely considered to be specific for the central nervous system (CNS), H3R is also expressed in a variety of cancers, suggesting a possible role tumorigenesis. Expression of H3R in breast carcinomas is correlated with the levels of proliferating cell nuclear antigen (PCNA) level and an increased level of malignancy [9]. Expression of H3R in malignant adrenocortical cancer samples is also up-regulated compared to normal tissues [10]. Additional studies confirmed that the upregulated expression of $\mathrm{H} 3 \mathrm{R}$ correlates with tumor progression. Activation of H3R by its agonist induces the proliferation and migration of pancreatic carcinoma PANC-1 cell and breast carcinomas MDA-MB-231 cells [9, 11]. However, it remains to be determined whether H3R is expressed in astrocytomas and whether H3R is involved in the regulation of invasiveness and the induction of EMT in these cells.

H3R functions as a presynaptic autoreceptor and heteroreceptor at numerous neurotransmission crossroads, and it regulates the release and synthesis of neurotransmitters, such as histamine, acetylcholine, dopamine, norepinephrine and 5-hydroxytryptamine [5-8]. It has been widely proven that H3R is involved in a series of neurological disorders, such as sleep disorders, Alzheimer's disease, schizophrenia and epilepsy $[12,13]$. At the meanwhile, H3R has multiple isoforms and can target a variety of signal transduction pathways in the nervous system. For example, H3R activation not only inhibits the adenylyl cyclase (AC) pathway, but also results in phosphorylation of the mitogen-activated protein kinase (MAPK), phosphatidyl inositol 3-kinase (PI3K), calmodulin-dependent protein kinase II (CaMKII) and phospholipase A2 (PLA2) signaling pathways [13-16]. H3R blockade offers protection in several conditions such as inflammation, N-methyl-D-aspartic acid (NMDA)induced neurotoxicity, ischemia-induced oxidative stress and autophagy [17-20]. Considering the high level of H3R expressionin the brain, its role in tumor progression, multiple signal transductions and general cerebral protection, we hypothesized that H3R may have a potential role in the regulation of the invasiveness and EMT of GBM.

In order to verify our hypothesis, the present studies were designed to (1) explore the H3R expression in the human astrocytoma tissues and cell lines by immunohistochemistry assay, real-time $\mathrm{qPCR}$ and western blot; (2) inhibit the overexpressed H3R by smallinterfering RNA (siRNA) or antagonist in the U87MG cells to evaluate the role of $\mathrm{H} 3 \mathrm{R}$ in the metastasis nature, EMT activators and markers in the U87MG cells; (3) explore the signaling pathways downstream of H3R by siRNAs or the selective agonist/antagonist in the U87MG cells; (4) explore the effects of knockdown or blockade of H3R on a xenografted model.

\section{RESULTS}

\section{Expression of H3R correlates with the pathology grade of astrocytoma}

To date, evidence for the expression of H3R in glioma was lacking and there was only one study reporting that $\mathrm{H} 3 \mathrm{R}$ is not expressed in $\mathrm{U} 373 \mathrm{MG}$ cells [21]. Here, 40 patients from Tangdu Hospital diagnosed with astrocytoma between 2008 and 2012 were selected, including 20 cases of low-grade astrocytoma (LGA: 10 cases of pilocytic astrocytoma (PA) and 10 cases of fibrillary astrocytoma (FA)) and 20 cases of high-grade astrocytoma (HGA: 10 cases of anaplastic astrocytoma (AA) and 10 cases of GBM). Ten samples of healthy normal brain tissue (NB) obtained from patients who underwent needle biopsy without malignancy served as control. The tissue samples were harvested and H3R expression was measured using immunohistochemistry, real-time PCR and western blot techniques.

Figure 1A shows that positive immunoreactivity of H3R was detected mostly in the soma of neurons in the NB tissues but not in the glia cells. In contrast, H3R expression was detected in glioma cells of astrocytoma tissues and was highest in the GBM tissue. Analysis using Image-Pro software showed that the percentage of expression area (PEA) and the mean density (MD) of H3R were significantly higher in the astrocytoma tissue than in the NB tissues, and both indexes were higher in the HGA than in the LGA $(P<0.01)$. In addition, the PEA and $\mathrm{MD}$ of $\mathrm{H} 3 \mathrm{R}$ protein expression in the GBM tissue were significantly higher than in the AA tissues $(P<0.01)$. These results were confirmed using real-time PCR and western blot techniques (Figures $1 \mathrm{~B}$ and $1 \mathrm{C}$ ). We found that LGA and HGA tissues had higher mRNA and protein expression levels of H3R than NB tissues $(P<0.01)$. In addition, the relative level of H3R mRNA and protein expression in HGA was significantly higher than that in the LGA $(P<0.01)$. Both mRNA and protein expression of H3R in the GBM were also significantly higher than in the AA $(P<0.01)$.

\section{H3R regulates U87MG cell proliferation}

H3R expression levels in the normal human astrocytes (hAstrocytes) and glioma cell lines (C6MG, IMR-32, U251MG, U87MG) were measured using realtime qPCR and western blot techniques. The results in Figure 2A showed that glioma cell lines had a significantly higher level of H3R mRNA expression than hAstrocytes. U87MG cells had the highest endogenous expression of H3R of the four glioma cell lines tested so it was selected for further in vitro experiments. In order to explore the role of H3R in these cells, a siRNA specific for H3R was employed. Western blot analysis of lysates of cells incubated with the H3R siRNAs (Figure 2B) 
$\mathbf{A}$
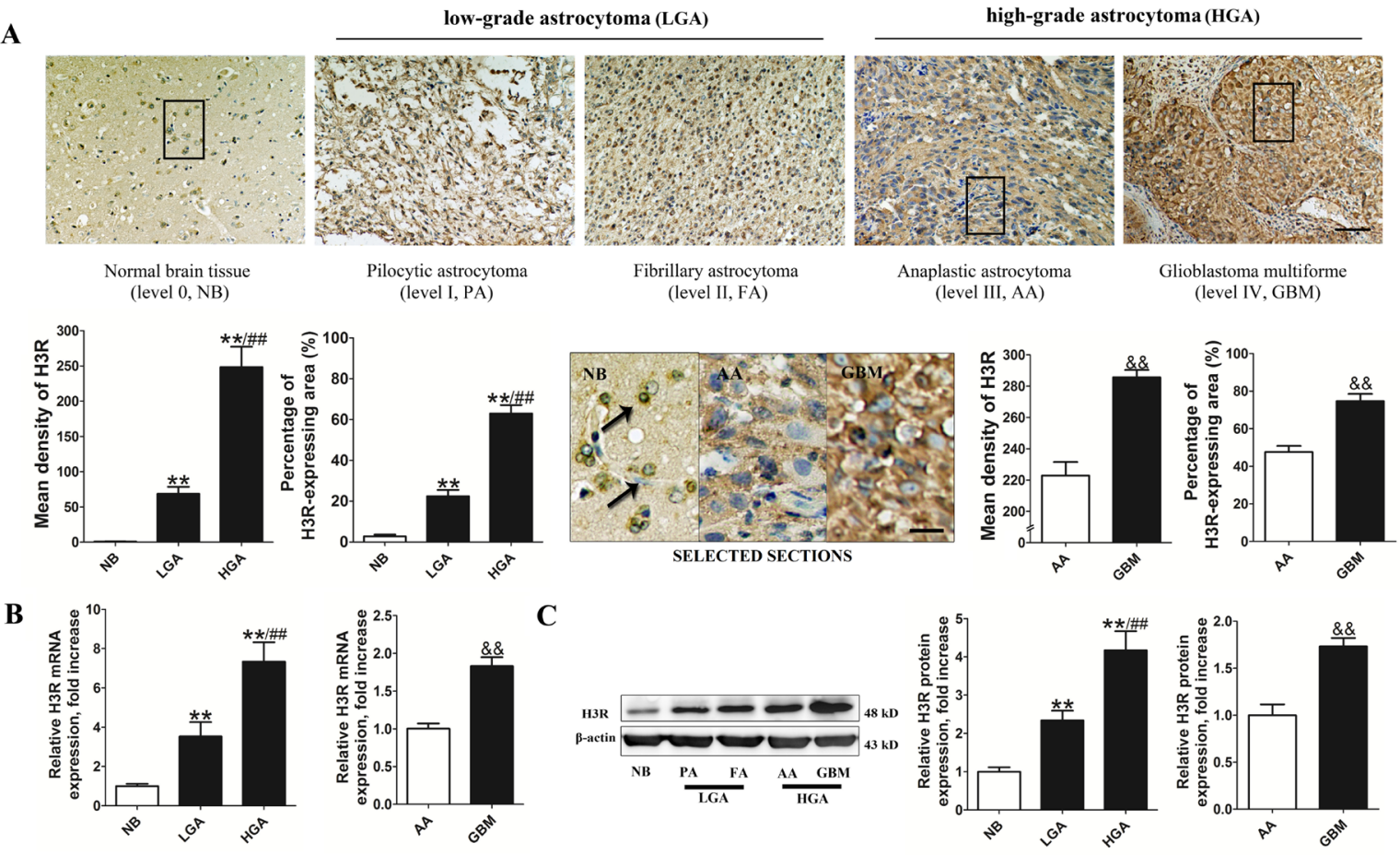

Figure 1: H3R was overexpressed in astrocytoma cells. A. Representative pictures of immunohistochemical labeling for H3R expression in astrocytoma and NB (bar $=100 \mu \mathrm{m}$ ). The comparison image in SELECTED SECTIONS consists of the selected boxes from the upper panel $(\mathrm{bar}=25 \mu \mathrm{m})$. B and C. Group results showing H3R expression from the RT-qPCR and western blot. Bars represent as mean \pm SD. ${ }^{* *} P<0.01$ vs. NB; ${ }^{\# \#} P<0.01$ vs. LGA; ${ }^{\&} P<0.01$ vs. AA; $n=10$ for each grade of tissue samples.
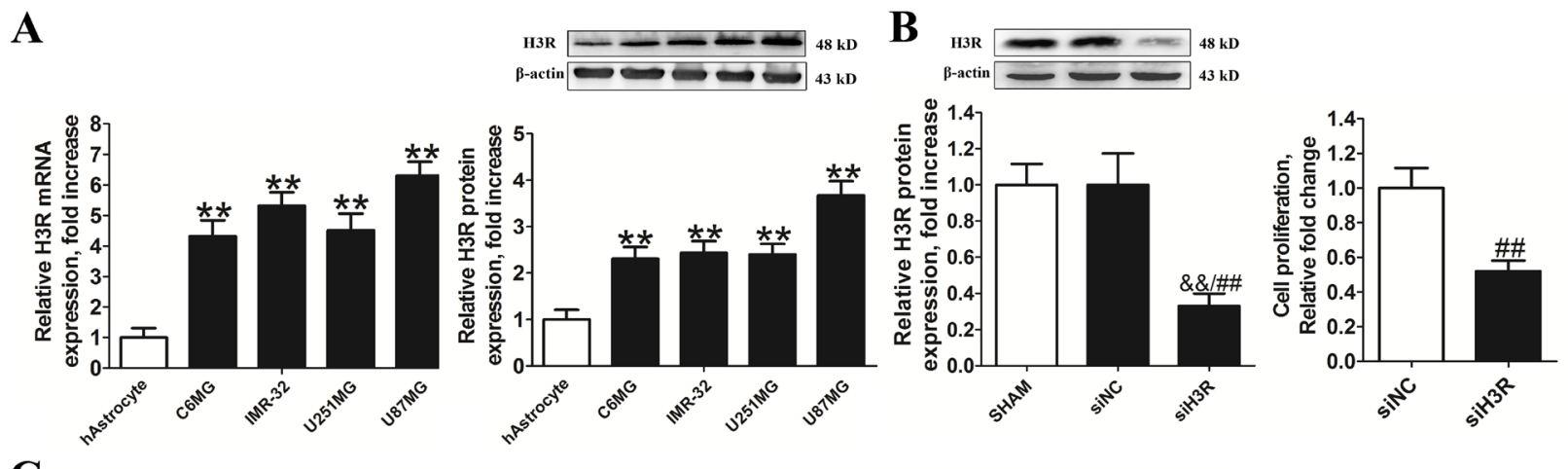

C
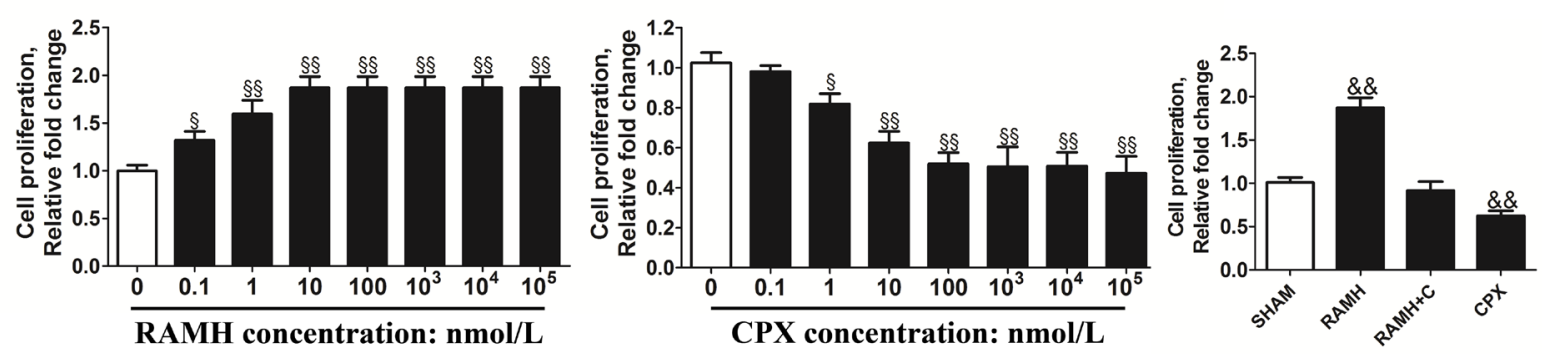

Figure 2: Inhibition of the H3R expression by siRNA or an antagonist decreased the proliferation of U87MG cells. A. Group results of H3R expression from the RT-qPCR and western blot in the glioma cells and the human astrocytes. B. The effects of H3R siRNA on the proliferation of U87MG cells. The specific siRNA for H3R significantly decreased H3R protein expression in U87MG cells and cell proliferation in U87MG cells. C. The effects of H3R agonist/antagonist on the cell proliferation of U87MG cells. U87MG cells were incubated with H3R agonist/antagonist and cell proliferation was measured. The effects of $100 \mathrm{nmol} / \mathrm{L} \mathrm{RAMH}$ on the proliferation of the U87MG cells were completely blocked by $100 \mathrm{nmol} / \mathrm{L} \mathrm{CPX}$. Bars represent as mean $\pm \mathrm{SD}$. $* * P<0.01$ vs. hAstrocyte; \&\& $P<0.01$ vs. SHAM; ${ }^{\#} P<0.01$ vs. siNC; ${ }^{\$} P<0.05$ vs. $0 ;{ }^{\$} P<0.01$ vs. $0 ; n=8$ for each group. 
showed that the knockdown efficiency of H3R was approximately 63\% in U87MG cells ( cells) compared to the negative control siRNA U87MG cells (siNC U87MG cells). Down-regulation of H3R expression was found to decrease cell proliferation in these cells as shown in Figure 2B $(P<0.01)$.

To further analyze the role of H3R, U87MG cells plated in 96-well plates $\left(1.5 \times 10^{4}\right.$ cells/well $)$ were incubated with the H3R selective agonist $(R)-(\alpha)-(-)-$ methylhistamine dihydrobromide (RAMH) or/and its antagonist ciproxifan (CPX). We found that pretreatment with the H3R selective agonist RAMH $\left(10^{-3}-10 \mu \mathrm{mol} / \mathrm{L}\right)$ promoted proliferation of U87MG cells in a dosedependent manner. In contrast, blocking H3R activity with an antagonist CPX $\left(10^{-3}-10 \mu \mathrm{mol} / \mathrm{L}\right)$ suppressed proliferation of U87MG cells in a dose-dependent manner (Figure 2C). Cell proliferation of U87MG cells following incubation with $100 \mathrm{nmol} / \mathrm{L}$ RAMH was blocked by $100 \mathrm{nmol} / \mathrm{L}$ CPX. Based on this, $100 \mathrm{nmol} / \mathrm{L}$ RAMH and CPX were used in subsequent experiments.

\section{Inhibition of H3R expression suppresses metastasis in U87MG cells}

We used the wound healing migration and the transwell invasion assays to determine whether $\mathrm{H} 3 \mathrm{R}$ can affect metastasis in U87MG cells (Figure 3A). We found that upon down-regulation of H3R expression using siRNA, migration of the U87MG cells towards artificially created wounds in confluent cell monolayers was suppressed as shown by the decreased number of migrating cells $(P<0.01)$. Down-regulation of H3R expression also resulted in fewer cells infiltrating the membranes in the transwell assay compared to the control $(P<0.01$, Figure 3B).

A selective H3R agonist and antagonist were used in parallel in the wound healing and transwell assays to confirm our results as shown in Figure 3C. We found that $\mathrm{H} 3 \mathrm{R}$ activation by RAMH induced a significant increase in migration compared to the control $(P<0.01)$, which was inhibited by CPX. In addition, blockade of H3R by CPX led to a sharp decline in migration $(P<0.01)$. As expected, RAMH increased the number of infiltrating U87MG cells in the transwell assay $(P<0.01$, Figure 3D), an effect that was inhibited by co-incubation with CPX. Lastly, the antagonist CPX reduced the number of migrating cells $(P<0.01)$.

\section{Inhibition of H3R expression suppresses EMT in U87MG cells}

The mRNA levels of the EMT-activators snail, slug and twist were measured in U87MG cells depleted of H3R. We found that all markers of EMT were significantly down-regulated compared with the control group $(P<0.01$, Figure 4A). In parallel, H3R down-regulation
A

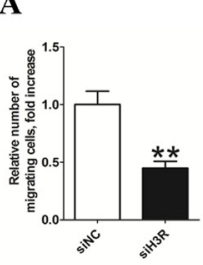

$\mathbf{C}$
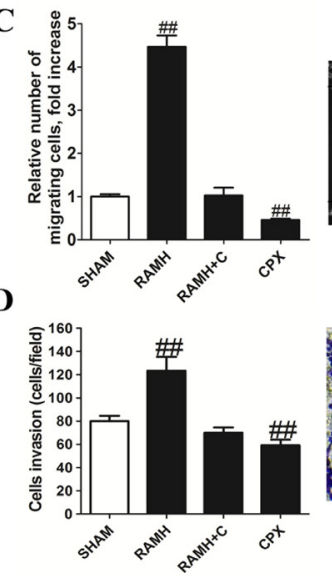
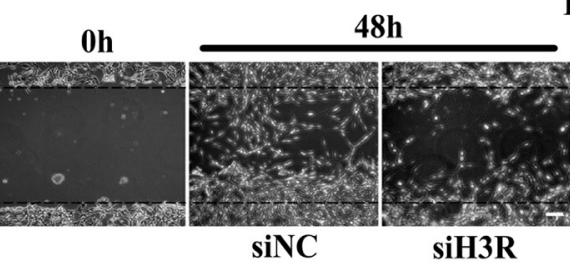

siNC

0h
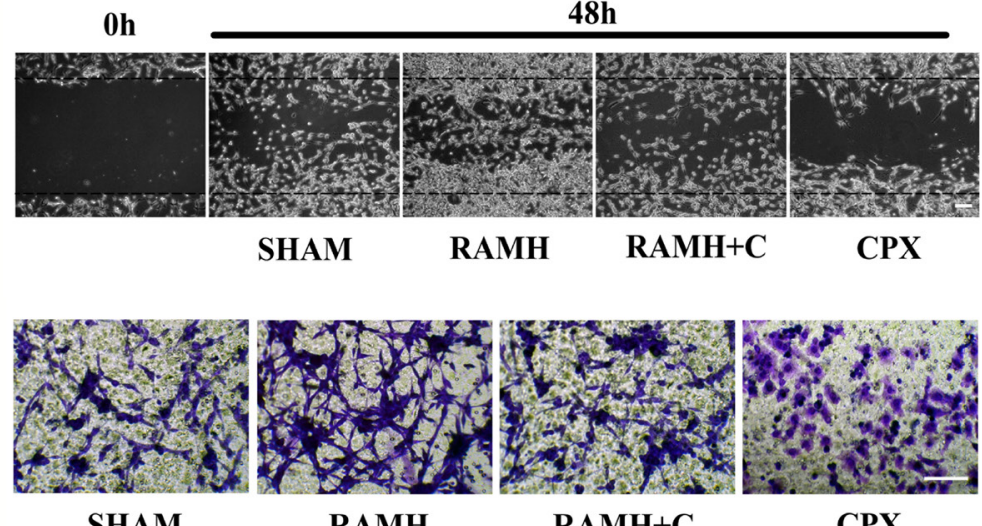

SHAM
B

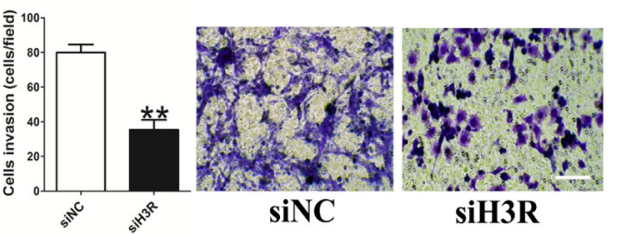

$48 \mathrm{~h}$

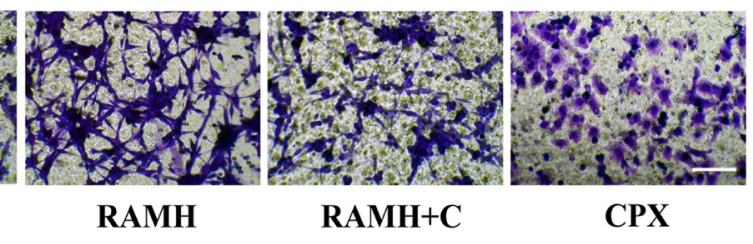

Figure 3: Inhibition of the H3R by the siRNA or CPX decreased the metastatic and invasive ability of U87MG cells. A and B. Group results from the wound healing migration assay and transwell invasion assay after down-regulation of H3R by siRNA. H3R down-regulation by siRNA inhibited cell migration and invasion of U87MG cells. C and D. Group results from the wound healing migration assay and transwell invasion assay after pretreatment with H3R agonist RAMH or/and antagonist CPX. H3R blockade by antagonist inhibited cell migration and invasion of U87MG cells. Bars represent as mean $\pm \mathrm{SD} . * * P<0.01 \mathrm{vs.} \mathrm{siNC;} P<0.01 \mathrm{vs.} \mathrm{SHAM}$; $n=8$ for each group. 
A

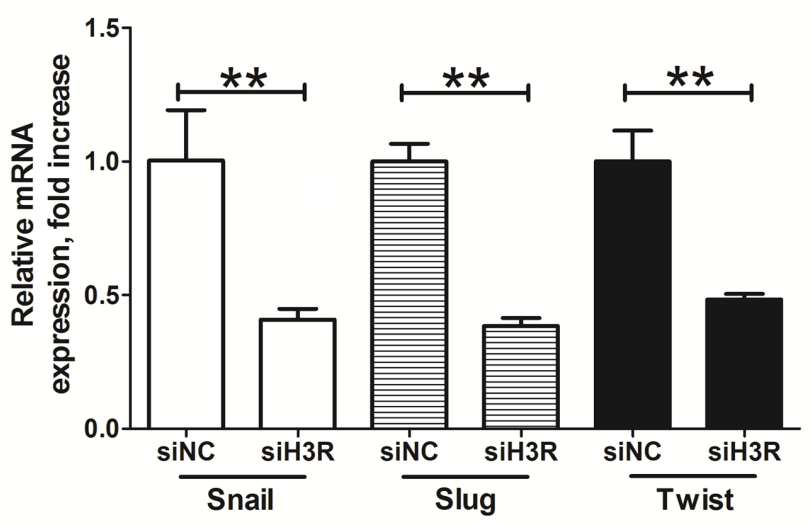

B
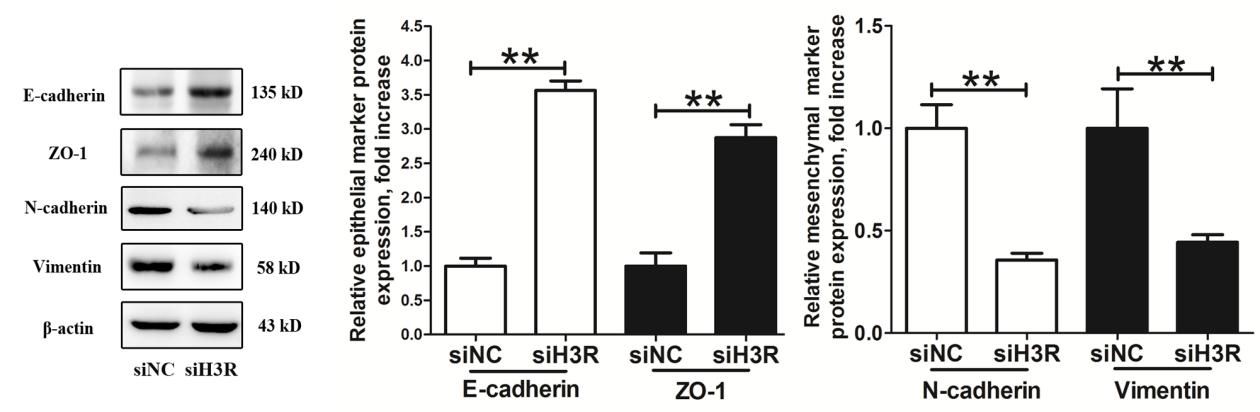

C
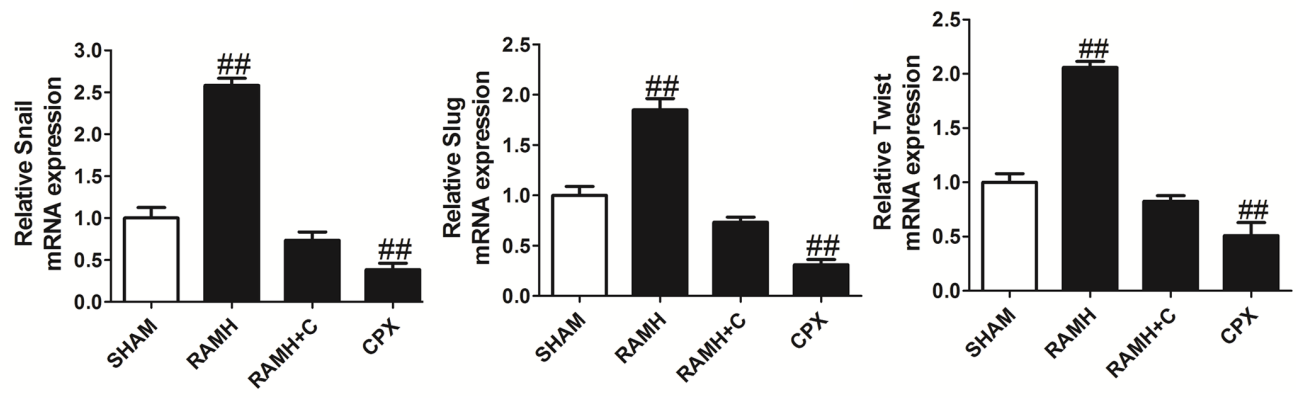

D
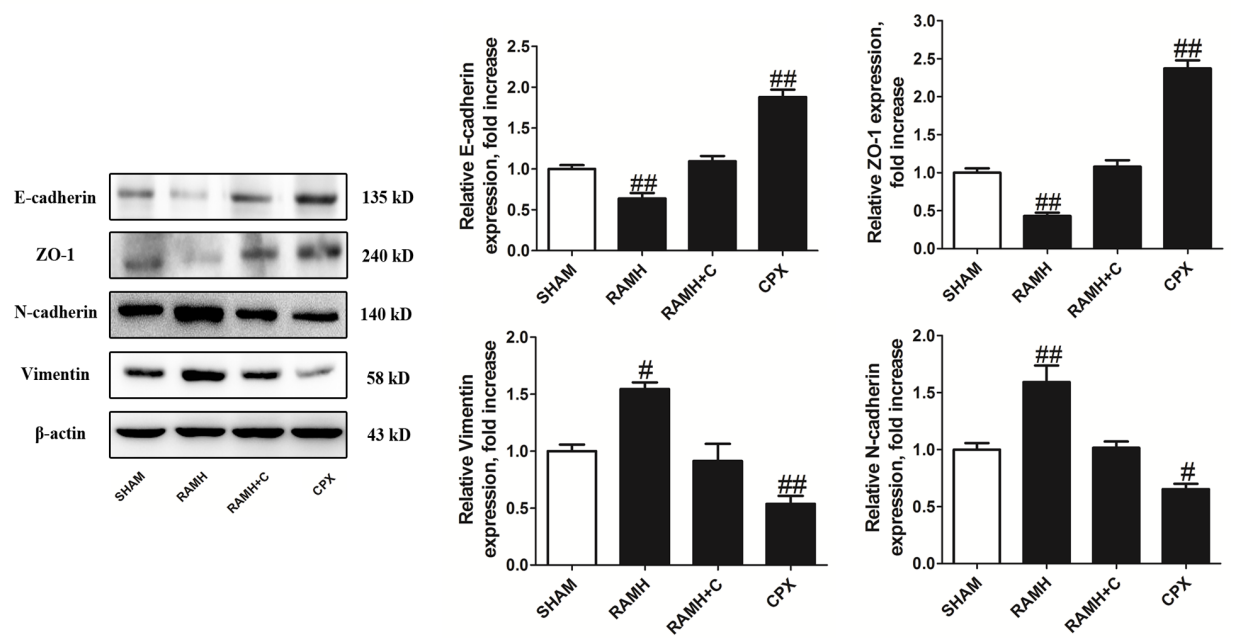

Figure 4: Inhibition of the H3R by the siRNA or CPX suppressed EMT progression in U87MG cells. A and B. Group results from the RT-qPCR and western blots after down-regulation of H3R expression using the siRNA. H3R down-regulation by the siRNA decreased EMT activators mRNA, increased epithelial markers (E-cadherin and ZO-1) and decreased mesenchymal markers (N-cadherin and vimentin) in U87MG cells. C and D. Group results from the RT-qPCR and western blot after pretreatment with the H3R agonist RAMH or/and the antagonist CPX. Blockade of H3R by CPX decreased EMT activators mRNA, increased epithelial marker (E-cadherin and ZO1) and decreased mesenchymal marker (N-cadherin and vimentin) in U87MG cells. Bars represent as mean $\pm \mathrm{SD}$. $* * P<0.01$ vs. siNC; ${ }^{\#} P<0.05$ vs. SHAM; ${ }^{\#} P<0.01$ vs. SHAM; $n=8$ for each group. 
also resulted in an up-regulation of the epithelial markers E-cadherin and ZO-1 and the down-regulation of the mesenchymal markers $\mathrm{N}$-cadherin and vimentin $(P<0.01$, Figure 4B).

Incubation with RAMH resulted in up-regulated mRNA expression of slug, snail and twist in U87MG cells $(P<0.01$, Figure $4 C)$, and this effect was blocked by CPX. Similarly, pretreatment with CPX resulted in downregulated mRNA levels of EMT activators $(P<0.01$, Figure 4C). Immunoblotting assays confirmed that the H3R selective agonist RAMH significantly increased the protein expression of $\mathrm{N}$-cadherin and vimentin while decreasing E-cadherin and ZO-1 in U87MG cells $(P<0.01$, Figure 4D). This effect was reversed by the selective $\mathrm{H} 3 \mathrm{R}$ antagonist $\mathrm{CPX}$. In addition, pretreatment with CPX up-regulated E-cadherin and ZO-1 expression and down-regulated $\mathrm{N}$-cadherin and vimentin in the U87MG cells $(P<0.01$, Figure 4D).

\section{H3R activates EMT via the PI3K/Akt and MEK/ ERK signaling pathways}

The Akt and ERK signaling pathways have been reported to play a role in modulating cell invasion and the progression of EMT. Here, we examined the effect of H3R on these two signaling pathways. We found that H3R down-regulation by siRNA significantly decreased the phosphorylation of PI3K, Akt, MEK and ERK, but not their total protein levels $(P<0.01$, Figure 5A). Similarly, treatment of cells with the H3R-selective agonist significantly increased the phosphorylation level of Akt, PI3K, ERK and MEK, while the H3R antagonist CPX significantly suppressed phosphorylation of PI3K, Akt, MEK and ERK $(P<0.01)$. In both cases, the total protein levels of PI3K, Akt, MEK and ERK $(P<0.01$, Figure 5B) remained unaffected as observed in untreated cells. Co-incubation with $100 \mathrm{nmol} / \mathrm{L}$ CPX suppressed 100 $\mathrm{nmol} / \mathrm{L}$ RAMH induced phosphorylation of PI3K, Akt, MEK and ERK. In addition, $100 \mathrm{ng} / \mathrm{mL}$ pertussis toxin (PTX) pretreatment completely prevented the activation observed following RAMH treatment $(P<0.01)$. These observations indicated that the H3R mediated activation of $\mathrm{PI} 3 \mathrm{~K} / \mathrm{Akt}$ and MEK/ERK signaling pathways in U87MG cells depended on PTX sensitive $\mathrm{G}_{\mathrm{i} / \mathrm{o}}$-proteins.

In order to verify the role of PI3K/Akt and MEK/ ERK signaling pathways in the H3R related cell invasion and EMT progression, siRNAs for Akt2 or ERK1 were used and the knockdown efficiencies for Akt and ERK were found to be $53 \%$ and $51 \%$ respectively in U87MG cells $(P<0.01$, Figure 5C). Down-regulation of Akt or ERK significantly attenuated the effects of RAMH on the protein levels of E-cadherin and vimentin compared to the negative control $(P<0.01$, Figure 5D). The results of the transwell assay showed that knockdown of Akt or ERK suppressed the RAMH mediated increase in the number of infiltrating cells $(P<0.01$, Figure 5D).
The antagonists for PI3K/Akt and MEK/ERK signaling pathways, LY294002 and U-0126, were also found to suppress the RAMH induced increase in migration of U87MG cells $(P<0.01$, Figure 5D). Correspondingly, LY294002 and U-0126 suppressed the RAMH induced up-regulation of N-cadherin and the down-regulation of E-cadherin $(P<0.01$, Figure 5D).

\section{H3R inhibition inhibits tumor growth in vivo}

To evaluate the effect of inhibition of H3R in vivo, we generated a subcutaneous xenograft model in nude mice. The rats were randomly assigned to one of the following four groups: (1) siNC group: nude rats were inoculated with the U87MG cells with mock-transfection for $4 \mathrm{w}$; (2) siH3R group: nude rats were inoculated with the U87MG cells transfected with H3R siRNAs for $4 \mathrm{w}$; (3) Vehicle group: nude rats were inoculated with the U87MG cells. When the subcutaneous tumors reached $50 \mathrm{~mm}^{3}$ (about $2 \mathrm{w}$ ), the nude rats received I.V. injections of vehicle $(0.9 \% \mathrm{NaCl})$ once a day for $4 \mathrm{w}$; (4) CPX group: nude rats were inoculated with the U87MG cells. When the subcutaneous tumors reached $50 \mathrm{~mm}^{3}$ (about $2 \mathrm{w}$ ), the nude rats received I.V. injections of CPX ( $3 \mathrm{mg} / \mathrm{kg})$ once a day for $4 \mathrm{w}$. After $4 \mathrm{w}$, the tumor volume in the siNC group is higher than that in the siH3R group $(P<0.01$, Figure 6A). Successive abdominal administration of $3 \mathrm{mg} / \mathrm{kg}$ CPX for $4 \mathrm{w}$ also induced a limited delay in tumor growth in the CPX group compared with the Vehicle group $(P<0.01$, Figure 6A). Furthermore, immunohistochemistry studies of tumor sections revealed that E-cadherin expression was significantly increased and $\mathrm{N}$-cadherin decreased in the siH3R group and CPX groups compared with the siNC group and Vehicle groups (Figure 6B). The western blot data of tumors in the siH3R and CPX groups also showed that the protein levels of E-cadherin increased significantly, while the mesenchymal phenotype marker $\mathrm{N}$-cadherin decreased compared with the siNC and Vehicle groups $(P<0.01$, Figure $6 \mathrm{C})$.

\section{DISCUSSION}

Expression of H3R has been reported for neurons [22-25]. More recent studies have reported expression of H3R in the cultured rat astrocytes from the cortex, cerebellum, hippocampus and striatum [26]. Consistent with these studies, our results showed that high levels of H3R expression are characteristic of neurons and lower levels are found in the glia cells of NB tissue and cultured hAstrocytes. In contrast, intense H3R staining was observed in the human glioma cells of astrocytoma tissue, especially in the GBM. Even though expression of H3R has not been documented for U373MG cells [21], examination of glioma cell lines (C6MG, IMR-32MG, U251MG, U87MG) revealed a relatively high level of 
A

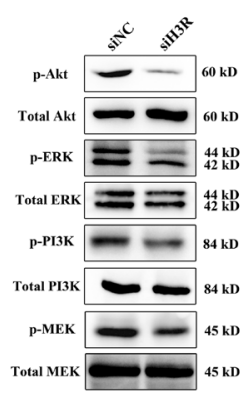

B
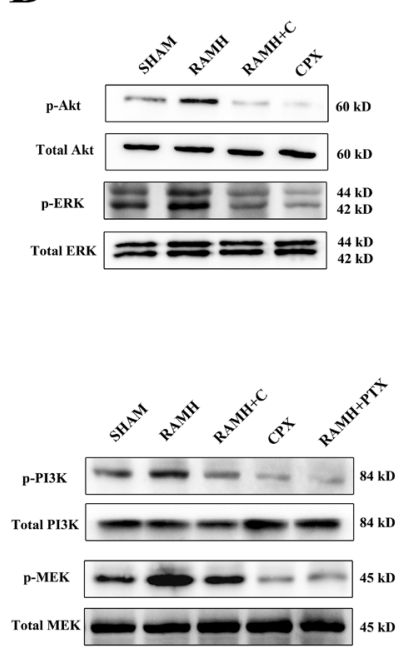

C

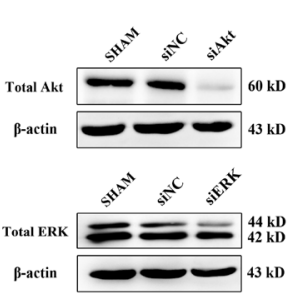

D

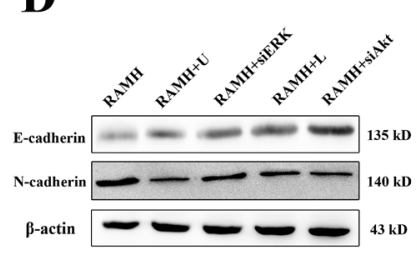

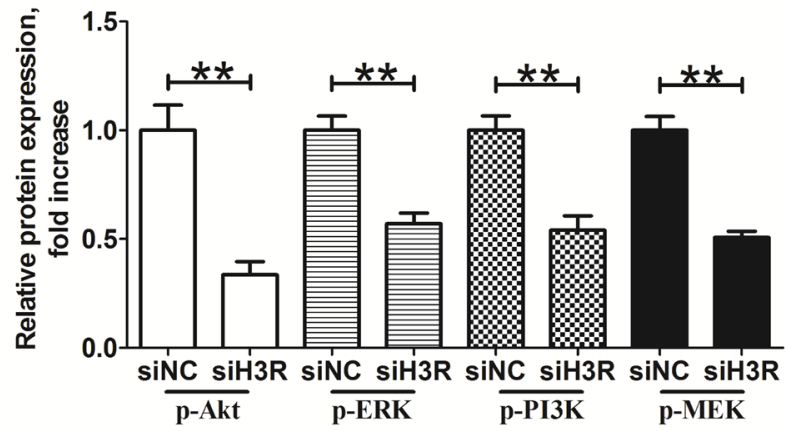
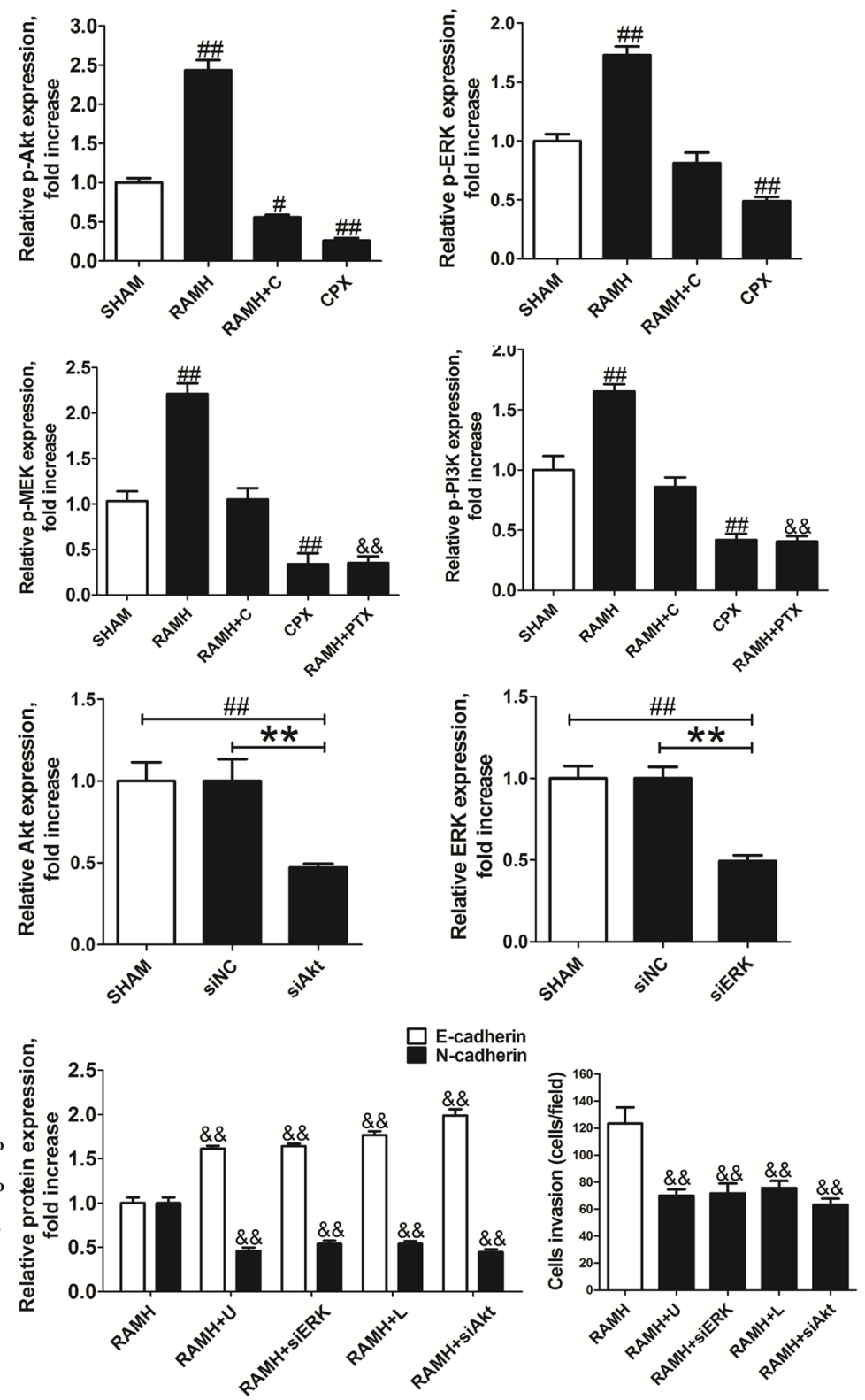

Figure 5: Inhibition of Akt/ERK by the siRNA or CPX suppressed RAMH-induced cell invasion or reorganization of the cadherin-household. A and B. Representative immunoblots of samples from U87MG cell lysates subjected to different treatments and their quantitative densitometric analysis. Inhibition of H3R by the siRNA or CPX suppressed the activation of PI3K/Akt and MEK/ ERK signaling pathways. C and D. Group results from western blot after application of Akt2/ERK1 siRNAs and antagonists. Applicantion of Akt2/ERK1 siRNAs significantly inhibited the Akt/ERK expression in the U87MG cells. Inhibition of Akt/ERK by siRNA or antagonist suppressed RAMH-induced cell invasion and reorganization of the cadherin-household; Bars represent as mean $\pm \mathrm{SD} . * * P<0.01$ vs. siNC; ${ }^{\#} P<0.01$ vs. SHAM; ${ }^{\#} P<0.01$ vs. SHAM; ${ }^{\&} \&<0.01$ vs. RAMH; $n=8$ for each group. 
A

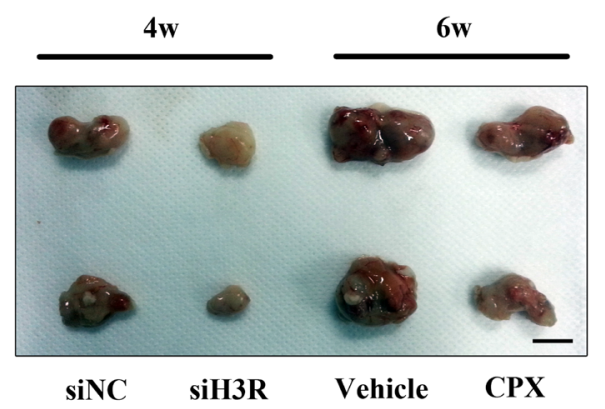

B

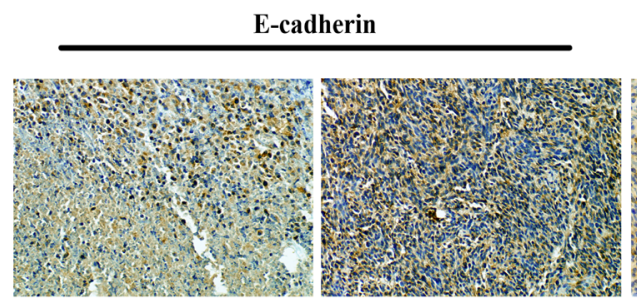

siNC

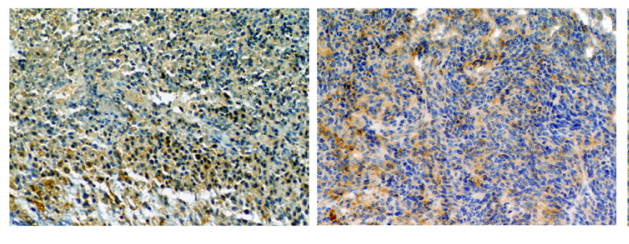

Vehicle
CPX
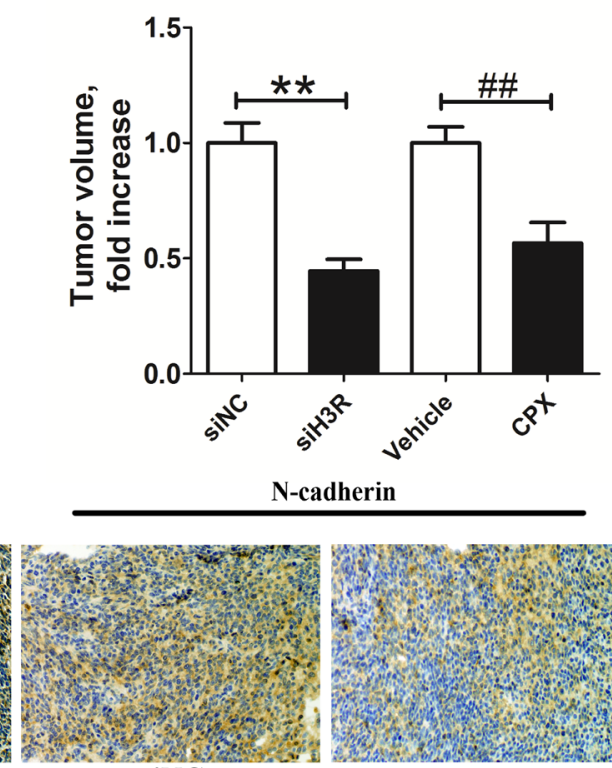

siNC

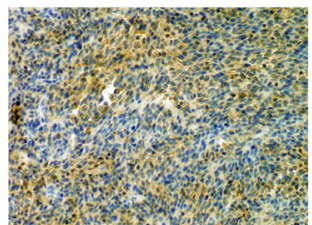

Vehicle

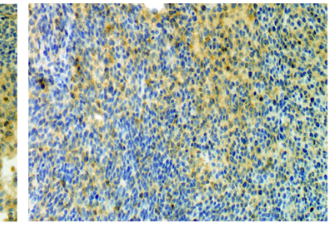

siH3R

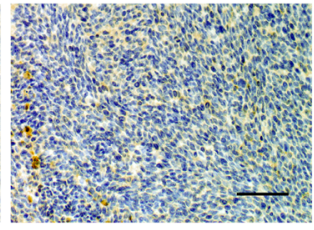

CPX

C
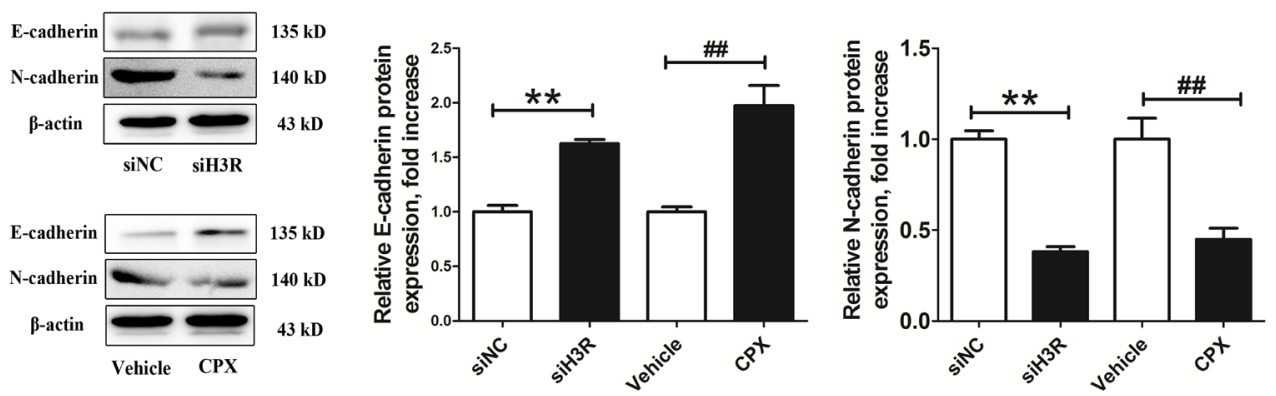

Figure 6: Inhibition of the H3R by the siRNA or CPX restrains the growth and EMT progression in a xenografted model. A. Group representative images of xenograft tumors and quantitative tumor volume analysis after treatment; B. Group representative pictures of immunohistochemical labeling for the epithelial and mesenchymal phenotype markers in the harvested tumor tissues (bar $=100$ $\mu \mathrm{m})$. C. Western blot assay for the expression of the epithelial and mesenchymal phenotype markers in the harvested tumor tissues and their quantitative densitometric analysis. Bars represent as mean $\pm \mathrm{SD}$. ${ }^{* *} P<0.01$ vs. siNC; ${ }^{\#} P<0.01$ vs. SHAM; $n=8$ for each group.

both H3R mRNA and protein compared to hAstrocytes. This atypical up-regulation of H3R in the glioma cells may be a presentation of neuronal differentiation pattern in glioma tumors. Further analysis of H3R showed that HGA had elevated mRNA and protein expression, increased PEA and MD of H3R than the LGA. Therefore, H3R expression correlates with the pathology grade and H3R may be a prognosis factor in astrocytoma.

The up-regulated expression of H3R in the GBM compared to other grades of astrocytomas suggested a possible role in tumor progression of the GBM. In order to investigate the role of H3R in tumor progression, we used the H3R antagonist CPX and a specific siRNA for $\mathrm{H} 3 \mathrm{R}$ in vitro and in vivo to down-regulate the activity or expression of the protein. Compared with other H3R antagonists, CPX exhibited a non-interactive antagonistic action with other histamine receptors and blockade of H3R by CPX showed protection in a series of pathologic conditions, such as schizophrenia, Alzheimer's disease and sleep disorders [27-29]. We found that inhibition of H3R by CPX or siRNA in U87MG cells significantly inhibited cell proliferation in vitro and in vivo, consistent 
with previous studies using the histamine receptor 1 and 2 in astrocytoma $[21,30]$. Interestingly, a previous study showed that the effect of H3R on tumor proliferation was tumor-dependent. For example, activation of H3R by agonists induced the proliferation of pancreatic carcinoma PANC-1 cells and breast carcinoma MDA-MB-231 cells $[9,11]$, while activation of H3R by an agonist suppressed the proliferation of hepatoma McA-RH7777 cells and cholangiocarcinoma Mz-ChA-1 cells [31, 32]. The factors that dicided whether H3R was a stimulatory or inhibitory receptor on the tumor proliferation were complex, including the characteristics of tumors, H3R isoforms and the complexity of the signal transduction pathways involved. First, activation of H3R by exogenous histamine suppressed the proliferation of hepatoma McA-RH7777 cells [31], while H3R blockade promoted proliferation due to an unrespected release of cytochrome P450 enzymes within the McA-RH7777 cells, which regulated cell proliferation by controlling the levels of growth regulatory factors [12]. Second, it has been documented that H3R isoforms couple to diverse G-proteins to diversify their signaling effects in different cell systems [14, 33]. Specifically, H3R stimulation by RAMH (acting via $\mathrm{G} \alpha_{\mathrm{i}}$ ) inhibited hyperplastic biliary growth by inhibition of cAMP [34], while RAMH (acting through $\mathrm{G} \alpha_{\mathrm{o}}$ ) decreased the growth of cholangiocarcinoma $\mathrm{Mz}-\mathrm{ChA}-1$ cells by inositol triphosphate $\left(\mathrm{IP}_{3}\right) / \mathrm{Ca}^{2+}$, which is independent of cAMP activation [32]. Third, H3R activation not only inhibited the adenylyl cyclase-cAMP dependent pathway, but also activated the MAPK, PI3K, CaMKII, and PLA signaling pathways [13-16]. In different tumors, the major signaling pathways mediated by H3R may be different, and H3R may promote the opposite effect on one signaling in the different tumors. For example, H3R activation by RAMH promoted the MAPK signaling in the hyperplastic biliary [34], while H3R activaiton suppressed MAPK signaling in the cholangiocarcinoma Mz-ChA-1 cells [32]. Taken together, the final effect of H3R activation on the tumor proliferation needs repeated test for verification. Our findings disclosed no conflicts with the existing knowledge.

Even though the role of H3R in tumor proliferation has been extensively documented, it remained to be determined whether H3R is involved in the regulation of invasion. Here we showed for the first time that inhibition of H3R suppressed migration and invasion of glioma cells in vitro, while activation of $\mathrm{H} 3 \mathrm{R}$ by an agonist had the opposite effect. Studies in GBMs showed that EMT (-like) processes are of clinical relevance in malignant brain tumors [35-37], which involved reorganization of the cadherin-household (switching from E-cadherin to N-cadherin) to break cell-to-cell contacts [38, 39]. Members of the Twist-, Slug- and Snail-family mediate increased GBM-cell motility and invasiveness both in vitro and in vivo as shown in animal studies and in patient-derived specimens [40-42]. In our studies, we found that knockdown of H3R expression suppressed the expression EMT-activators (Twist, Slug and Snail) and restored the expression of epithelial cell markers (E-cadherin and ZO-1) while blockade of its activity down-regulated the expression of mesenchymal cell markers (N-cadherin and Vimentin) in glioma U87MG cells. Taken together, inhibition of H3R expression or activity in glioma cells suppressed tumor invasion and reversed EMT, suggesting that targeting H3R signaling in GBM may be a promising anticancer strategy.

A possible explanation for the different tumor behaviors of GBM is the deregulation of signal transduction pathways such as the PI3K/Akt and MEK/ ERK pathways caused by a large number of genetic abnormalities [43]. A large number of downstream molecules and crosstalk of these two signaling pathways exert a wide range of influences on GBM [43]. Previous studies reported that both the PI3K/Akt and MEK/ERK pathways are constitutively up-regulated in the majority of GBMs, which helps the unrestricted growth of glioma cells and enhances tumor invasion [44-47]. Moreover, the activation of these pathways plays a role in the progression of EMT $[48,49]$. Here we report that upon downregulation of $\mathrm{H} 3 \mathrm{R}$ expression or activity, activation of the PI3K/Akt and MEK/ERK signaling pathways was suppressed, while activation of H3R by RAMH induced activation of both signaling pathways in a PTX-sensitive $\mathrm{G}_{\mathrm{i} / \mathrm{o}}$ protein manner. In order to further demonstrate the role of above signaling pathways in the H3R related cell invasion and EMT progress, we applied the selective antagonist or we downregulated the expression of signaling components of the PI3K/Akt and MEK/ERK pathways. Either knockdown or blockade of the PI3K/Akt or MEK/ERK signaling pathways inhibited RAMH-mediated increase in cell invasion and reorganization of the cadherin-household, confirming that PI3K/Akt and MEK/ERK signaling pathways play a role in the H3R-mediated tumor invasion and EMT progression.

Since histamine and histamine receptors were discovered, the evidence of their role in oncology, including astrocytoma. It has been suggested that there are multiple and context-dependent effects of H3R on proliferation in tumors. However, direct evidence of the expression of H3R in glioma or an understanding of its involvement in tumor invasion and EMT progress was lacking. Here we found that H3R was over-expressed in glioma cells and tissues and inhibition of H3R suppressed invasion and EMT in glioblastoma through the PI3K/ Akt and MEK/ERK signaling pathways. The biological functions of H3R found in this study provided a basis for additional pathological and clinical investigations, suggesting that H3R may be a novel target for therapeutic intervention in GBM. 


\section{MATERIALS AND METHODS}

\section{Patient samples}

The protocol for this study was approved by the ethics committee of the Fourth Military Medical University. Forty patients from the Tangdu Hospital diagnosed with astrocytoma between 2008 and 2012 were selected for the study. All patients involved in the study provided consent. Patients with other medical conditions or those who received treatment prior to surgery were also excluded. The pathological specimens were reviewed, and histological classifications of astrocytoma were made based on the World Health Organization (WHO) Classification of brain tumors [50]. We identified 20 cases of LGA ( 10 cases of PA and 10 cases of FA) and 20 cases of HGA ( 10 cases of AA and 10 cases of GBM). Ten healthy NB obtained from patients who underwent needle biopsy without malignancy served as controls. All the slides were re-examined by two pathologists to ensure correct diagnosis. Tissue samples were harvested for immunohistochemistry assay, real-time PCR and western blot analysis.

\section{Cell lines}

Human glioma cell lines, C6MG, IMR-32, U87MG and $\mathrm{U} 251 \mathrm{MG}$ cells were purchased from the American Type Culture Collection (Rockville) and the Cell Bank of the Chinese Academy of Sciences. Cells were cultured using Dulbecco's modified Eagle's medium (DMEM) supplemented with $10 \%$ heat-inactivated fetal bovine serum (FBS) and $1 \%$ penicillin-streptomycin antibiotics. Normal human astrocytes (hAstrocytes) were obtained from ScienCell and propagated in astrocyte medium (ScienCell).

\section{Small interfering RNAs (siRNA)}

U87MG cells growing in 6-well plates were incubated with human siRNAs (100 nmol/L) for H3R/ Akt2/ERK1. Mock-transfection was performed using a negative control siRNA (Santa Cruz Biotechnology) as control. Cells were harvested at $48 \mathrm{~h}$ post transfection, washed and stored for future experiments. The knockdown efficiency was assessed using the western blot assay.

\section{Cell proliferation assay}

Cells were plated in 96-well plates $\left(1.5 \times 10^{4}\right.$ cells/ well) for $24 \mathrm{~h}$. At this time, $10 \mu \mathrm{L}$ CCK-8 reagent (Dojindo) was added to each well and then the plates were incubated at $37^{\circ} \mathrm{C}$ for $90 \mathrm{~min}$. Absorbance was measured using a Microplate Reader (Bio-Rad).

\section{Wound healing migration assay}

The siH3R U87MG cells and siNC U87MG cells were seeded in 6-well dishes and cultured under starvation conditions overnight until they reached $80 \%-90 \%$ confluence. A sterile one-milliliter pipette tip was used to generate a wound across the cell monolayer, and the debris was washed with PBS. In parallel, U87MG cells were were treated with an $\mathrm{H} 3 \mathrm{R}$ agonist/antagonist. After $48 \mathrm{~h}$, cells migrating into the wounded area or protruding from the border of the wound were visualized, photographed and counted under the inverted microscope. A total of nine areas were selected randomly in each well using a $100 \times$ magnification and cells in three wells of each group were counted for each experiment. Experiments were carried out in triplicate for a minimum of three times.

\section{Invasion assay}

The upper chamber of a 24-well hanging cell culture insert was pre-coated with $24 \mu \mathrm{g} / \mu$ l Matrigel (BD Biosciences). $5 \times 10^{5}$ U87MG cells were resuspended in $200 \mu \mathrm{L}$ serum-free media and seeded onto the upper chamber of a 24-well hanging cell culture insert (Millipore) fitted with polyethylene terephthalate ( $8.0 \mathrm{~mm}$ pore size). The agonist/antagonists for H3R, PI3K, MEK or the $G_{i / o}$ protein (all from Santa Cruz Biotechnology) were then added to the upper chamber as follows $(100 \mu \mathrm{mol} / \mathrm{L} \mathrm{LY} 294002$ for PI3K; $10 \mu \mathrm{mol} / \mathrm{L}$ $\mathrm{U}-0126$ for MEK; $100 \mathrm{ng} / \mathrm{mL}$ PTX for $\mathrm{G}_{\mathrm{i} / \mathrm{o}}$ protein) and $900 \mu \mathrm{l}$ DMEM media with $20 \%$ FBS was added to lower chamber of each well. After $48 \mathrm{~h}$, cells were fixed using $4 \%$ paraformaldehyde and dyed with crystal violet. Cells on the top surface of the insert were removed with a cotton swab. Cells adhering to the lower surface were fixed with methanol, stained with Giemsa solution and counted under a microscope in five predetermined fields $(200 \times)$.

\section{Xenograft tumor establishment}

All animal procedures were performed following the National Animal Experimentation guidelines and were approved by the ethics committee of the Fourth Military Medical University. All mice were bred in aseptic conditions at a constant humidity and temperature with standard $12 \mathrm{~h}$ light-dark cycles and free access to drinking water and standard chow. U87MG cells $\left(1 \times 10^{7}\right.$ in $100 \mathrm{~mL}$ of saline) were suspended in a volume of $0.2 \mathrm{ml}$ serumfree medium and injected subcutaneously into the hind flanks of the animals. At the end of the treatment, the nude rats were sacrificed and tumor volumes were calculated $\left(0.5 \times\right.$ length $(\mathrm{mm}) \times$ width $^{2}\left(\mathrm{~mm}^{2}\right)$. Tumors were harvested, fixed in formalin and embedded in paraffin. 


\section{Immunohistochemistry assays}

The pathology specimens were quickly removed, post fixed overnight at $4^{\circ} \mathrm{C}$, dehydrated in graded sucrose and processed for embedding in paraffin wax with the anatomical orientation preserved. Sections $3-4 \mu \mathrm{m}$ in thickness were mounted on silane-coated slides and airdried. Before immunohistochemistry staining, sections were placed in a bathing solution of $3 \% \mathrm{H}_{2} \mathrm{O}_{2}$ and $60 \%$ methanol PBS (pH 7.4) for 30 min and then treated with $0.01 \mathrm{~mol} / \mathrm{L}$ sodium citrate buffer at $95^{\circ} \mathrm{C}$ in a microwave oven for $13 \mathrm{~min}$ (antigen retrieval). Specimens were blocked using a $5 \%$ normal goat serum and $5 \%$ bovine serum albumin in PBS. Before each step, sections were rinsed three times in PBS buffer. Incubation with H3R primary antibodies (1:100, Abcam) was performed in a PBS-based solution of $1 \%$ bovine serum albumin for $12 \mathrm{~h}$ at $4^{\circ} \mathrm{C}$ in the recommended dilutions. After rinsing with $\mathrm{PBS}$, sections were incubated with the corresponding secondary biotinylated antibodies for $1 \mathrm{~h}$ at room temperature. A streptavidin/horseradish peroxidase complex was then applied as a detection system for $1 \mathrm{~h}$ (1:100; Abcam). Finally, staining was developed using 3, 3'diaminobenzidine tetra-hydrochloride in $0.05 \mathrm{~mol} / \mathrm{L}$ Tris- $\mathrm{HCl}$ buffer and $0.1 \% \mathrm{H}_{2} \mathrm{O}_{2}$. Negative control sections were incubated without the primary antibody.

\section{Image analysis}

Image analysis was performed using a DMR-X microscope coupled to a DC500 digital camera (Leica) and the image analysis system Quantimet Q550 (Leica). Nine randomly selected discontinuous fields $(20 \times)$ per samples were evaluated. The positive area, total area and the integrated optical density of H3R were stained and quantified using the Image-Pro Plus software (Media Cybernetics). The PEA was measured as positive area/total area $\times 100 \%$. The MD of H3R expression in a selected discontinuous fields was measured as the integrated optical density/total area $\times 1000$. The average of PEA and MD form the above nine fields were calculated as the behalf of a sample for the further data analysis.

\section{Real-time PCR analysis}

Tissue samples and cells were put into liquid nitrogen for $10 \mathrm{~min}$ and then into an ultra freezer at $80^{\circ} \mathrm{C}$. Total RNA was extracted from glioma cell lines and sample tissues using the Trizol reagent according to the manufacturer's instructions (Takara). RNA was transcribed to cDNA using the PrimeScript RT reagent Kit (Takara). For H3R expression analysis, the products were separated by electrophoresis on $1.5 \%(\mathrm{v} / \mathrm{v})$ agarose gels, stained with ethidium bromide, and visualized under UV light. The qRT-PCR for other investigated genes was performed using the CFX96TM real-time system (Bio-Rad), and the relative gene expression was normalized to the internal control $\beta$-actin. The primers used were as follows: H3R: Forward: 5'-TCATCGTGAGCATCTTTGGG-3', Reverse: 5'-ACAGAGGGTAGAGG ACAGGGTT-3'; Snail: Forward: 5'-TTTACCTTCCAGCAGCCCTA-3', Reverse: 5'-GACAGAGTCCCAGATGAGCA-3'; Slug: Forward: 5'-ACAGCGAACTGGAC ACACAT-3', Reverse: 5'-GGAATGGAGCAGCGGTAGT-3'; Twist: Forward: 5'-CACCATCCTCACACCTCTGC-3', Reverse: 5'-GCTGATTGGCACGACCTCT-3'.

\section{Western blot assay}

Proteins were extracted from tissue samples or cells. Total protein concentration was determined using a bicinchoninic acid (BCA) kit for protein determination (Takara). The samples were resolved in 10\% SDS-PAGE gels and transferred to polyvinylidene fluoride (PVDF) membranes. Immunoblots were probed with primary antibodies overnight at $4{ }^{\circ} \mathrm{C}$. The following antibodies used were from Abcam: H3R (1:1000), E-cadherin (1:10000), $\mathrm{N}$-cadherin (1:5000), ZO-1 (1:50), vimentin (1:1000), phospho-PI3K (Tyr607)(1:500). The following antibodies were from Cell Signaling: phospho-Akt (Ser473) (1:1000), Akt (1:1000), phospho-ERK1/2 (Thr202/Tyr204)(1:1000), ERK1/2 (1:1000), phospho-MEK1/2 (Ser217/Ser221) (1:1000), MEK1/2 (1:1000), PI3K (1:1000) and $\beta$-actin $(1: 1000)$. All primary antibodies were used according to the instructions provided by the supplier. After that, the membrane was incubated with the corresponding HRPlinked anti-rabbit IgG antibody (1:2000, Cell signaling) at room temperature for $1 \mathrm{~h}$. The blots were visualized using the ECL-Plus reagent (Millipore).

\section{Statistical analysis}

SPSS 16.0 (SPSS Inc) and Graph Pad Prism 5.0 software (Graph Pad Software) were used to analyze the data and all values were expressed as mean \pm SD. Statistical analysis was performed using one-way ANOVA (Analysis of Variance) followed by Bonferroni's multiple comparison tests where appropriate. The Mann-Whitney $U$ test was used for data with heterogeneity of variance. A value of $P<0.05$ was considered significant.

\section{ACKNOWLEDGMENTS}

This work was supported by National Natural Science Foundation of China (No. 31270952, 81102217).

\section{REFERENCES}

1. Xie Q, Mittal S, Berens ME. Targeting adaptive glioblastoma: an overview of proliferation and invasion. Neuro Oncol. 2014; 16:1575-1584. 
2. Vehlow A, Cordes N. Invasion as target for therapy of glioblastoma multiforme. Biochim Biophys Acta. 2013; 1836:236-244.

3. Kahlert UD, Nikkhah G, Maciaczyk J. Epithelial-tomesenchymal(-like) transition as a relevant molecular event in malignant gliomas. Cancer Lett. 2013; 331:131-138.

4. Lin YC, Lin JC, Hung CM, Chen Y, Liu LC, Chang TC, Kao JY, Ho CT, Way TD. Osthole inhibits insulin-like growth factor-1-induced epithelial to mesenchymal transition via the inhibition of PI3K/Akt signaling pathway in human brain cancer cells. J Agric Food Chem. 2014; 62:5061-5071.

5. Blaya B, Nicolau-Galmés F, Jangi SM, Ortega-Martínez I, Alonso-Tejerina E, Burgos-Bretones J, Pérez-Yarza G, Asumendi A, Boyano MD. Histamine and histamine receptor antagonists in cancer biology. Inflamm Allergy Drug Targets. 2010; 9:146-157.

6. Schlicker E, Fink K, Hinterthaner M, Gothert M. Inhibition of noradrenaline release in the rat brain cortex via presynaptic H3 receptors. Naunyn Schmiedebergs Arch Pharmacol. 1989; 340:633-638.

7. Schlicker E, Fink K, Detzner M, Gothert M. Histamine inhibits dopamine release in the mouse striatum via presynaptic H3 receptors. J Neural transm Gen Sect. 1993; 93:1-10.

8. Schlicker E, Betz R, Gothert M. Histamine H3 receptormediated inhibition of serotonin release in the rat brain cortex. Naunyn Schmiedebergs Arch Pharmacol. 1988; 337:588-590.

9. Medina V, Croci M, Crescenti E, Mohamad N, SanchezJiménez F, Massari N, Nuñez M, Cricco G, Martin G, Bergoc R, Rivera E. The role of histamine in human mammary carcinogenesis: $\mathrm{H} 3$ and $\mathrm{H} 4$ receptors as potential therapeutic targets for breast cancer treatment. Cancer Biol Ther. 2008; 7:2835.

10. Szabo PM, Wiener Z, Tombol Z, Kovacs A, Pocza P, Horanyi J, Kulka J, Riesz P, Toth M, Patocs A, Gaillard RC, Falus A, Racz K, Igaz P. Differences in the expression of histamine-related genes and proteins in normal human adrenal cortex and adrenocortical tumors. Virchows Arch. 2009; 455:133-142.

11. Cricco GP, Mohamad NA, Sambuco LA, Genre F, Croci M, Gutiérrez AS, Medina VA, Bergoc RM, Rivera ES, Martín GA. Histamine regulates pancreatic carcinoma cell growth through $\mathrm{H} 3$ and $\mathrm{H} 4$ receptors. Inflamm Res. 2008; 57:S23-24.

12. Bhowmik M, Khanam R, Vohora D. Histamine H3 receptor antagonists in relation to epilepsy and neurodegeneration: a systemic consideration of recent progress and perspectives. Br J Pharmacol. 2012; 167:1398-1414.

13. Vohora D, Bhowmik M. Histamine $\mathrm{H} 3$ receptor antagonists/ inverse agonists on cognitive and motor processes: relevance to Alzheimer's disease, ADHD, schizophrenia, and drug abuse. Front Syst Neurosci. 2012; 6:72.

14. Levi R, Seyedi N, Schaefer U, Estephan R, Mackins CJ, Tyler E, Silver RB. Histamine H3-receptor signaling in cardiac sympathetic nerves: Identification of a novel MAPKPLA2-COX-PGE2-EP3R pathway. Biochem Pharmacol. 2007; 73:1146-1156.

15. Moreno E, Hoffmann H, Gonzalez-Sepulveda M, Navarro G, Casado V, Cortes A, Mallol J, Vignes M, McCormick PJ, Canela EI, Lluis C, Moratalla R, Ferre S, Ortiz J, Franco R. Dopamine D1-histamine $\mathrm{H} 3$ receptor heteromers provide a selective link to MAPK signaling in GABAergic neurons of the direct striatal pathway. J Biol Chem. 2011; 286:5846-5854.

16. Bongers G, Sallmen T, Passani MB, Mariottini C, Wendelin D, Lozada A, Marle Av, Navis M, Blandina P, Bakker RA, Panula P, Leurs R. The Akt/GSK-3 $\beta$ axis as a new signaling pathway of the histamine H3 receptor. J Neurochem. 2007; 103:248-258.

17. Akhtar M, Pillai K, Vohora D. Effect of thioperamide on oxidative stress markers in middle cerebral artery occlusion model of focal cerebral ischemia in rats. Hum Exp Toxicol. 2008; 27:761-767.

18. Dai H, Fu Q, Shen Y, Hu W, Zhang Z, Timmerman H, Leurs R, Chen Z. The histamine H3 receptor antagonist clobenpropit enhances GABA release to protect against NMDA-induced excitotoxicity through the cAMP/ protein kinase A pathway in cultured cortical neurons. Eur J Pharmacol. 2007; 563:117-123.

19. Yan H, Zhang X, Hu W, Ma J, Hou W, Zhang X, Wang X, Gao J, Shen Y, Lv J, Ohtsu H, Han F, Wang G, Chen Z. Histamine $\mathrm{H} 3$ receptors aggravate cerebral ischaemic injury by histamine-independent mechanisms. Nat Commun. 2014; 25:3334.

20. Zhang DD, Sisignano M, Schuh CD, Sander K, Stark H, Scholich K. Overdose of the histamine H(3) inverse agonist pitolisant increases thermal pain thresholds. Inflamm Res. 2012; 61:1283-1291.

21. Hernandez-Angeles A, Soria-Jasso LE, Ortega A, AriasMontano JA. Histamine H1 receptor activation stimulates mitogenesis in human astrocytoma U373 MG cells. J Neurooncol. 2001; 55:81-89.

22. Coge F, Guenin SP, Audinot V, Renouard-Try A, Beauverger P, Macia C, Ouvry C, Nagel N, Rique H, Boutin JA, Galizzi JP. Genomic organization and characterization of splice variants of the human histamine $\mathrm{H} 3$ receptor. Biochem J. 2001; 355:279-288.

23. Leurs R, Bakker RA, Timmerman H, de Esch IJ. The histamine $\mathrm{H} 3$ receptor: from gene cloning to $\mathrm{H} 3$ receptor drugs. Nat Rev Drug Discov. 2005; 4:107-120.

24. Bakker RA. Histamine H3-receptor isoforms. Inflamm Res. 2004; 53:509-516. 
25. Bongers G, Bakker RA, Leurs R. Molecular aspects of the histamine H3 receptor. Biochem Pharmacol. 2007; 73:1195-1204.

26. Mele T, Juric DM. Identification and pharmacological characterization of the histamine $\mathrm{H}$ receptor in cultured rat astrocytes. Eur J Pharmacol. 2013. DOI: 10.1016/ j.ejphar. 2013.

27. Motawaj M, Arrang JM. Ciproxifan, a histamine $\mathrm{H}(3)$-receptor antagonist/inverse agonist, modulates methamphetamine-induced sensitization in mice. European J Neurosci. 2011; 33:1197-1204.

28. Bardgett ME, Davis NN, Schultheis PJ, Griffith MS. Ciproxifan, an $\mathrm{H} 3$ receptor antagonist, alleviates hyperactivity and cognitive deficits in the APP Tg2576 mouse model of Alzheimer's disease. Neurobiol Learn Mem. 2011; 95:64-72.

29. Chauveau F, Laudereau K, Libourel PA, Gervasoni D, Thomasson J, Poly B, Pierard C, Beracochea D. Ciproxifan improves working memory through increased prefrontal cortex neural activity in sleep-restricted mice. Neuropharmacology. 2014; 85:349-356.

30. Panula P, Lintunen M, Karlstedt K. Histamine in brain development and tumors. Semin Cancer Biol. 2000; 10:1114

31. Davenas E, Rouleau A, Morisset S, Arrang JM. Autoregulation of McA-RH7777 hepatoma cell proliferation by histamine H3 receptors. J Pharmacol Exp Ther. 2008; 326:406-413.

32. Francis H, Onori P, Gaudio E, Franchitto A, DeMorrow S, Venter J, Kopriva S, Carpino G, Mancinelli R, White M, Meng F, Vetuschi A, Sferra R, Alpini G. H3 Histamine Receptor-Mediated Activation of Protein Kinase $\mathrm{C} \alpha$ Inhibits the Growth of Cholangiocarcinoma In vitro and In vivo. Mol Cancer Res. 2009; 7:1704-1713.

33. Drutel G, Peitsaro N, Karlstedt K, Wieland K, Smit MJ, Timmerman H, Panula P, Leurs R. Identification of rat H3 receptor isoforms with different brain expression and signaling properties. Mol Pharmacol. 2001; 59:1-8.

34. Francis H, Franchitto A, Ueno Y, Glaser S, DeMorrow S, Venter J, Gaudio E, Alvaro D, Fava G, Marzioni M, Vaculin B, Alpini G. H3 histamine receptor agonist inhibits biliary growth of BDL rats by downregulation of the cAMP-dependent PKA/ERK1/2/ELK-1 pathway. Lab Invest. 2007; 87:473-487.

35. Verhaak RG, Hoadley KA, Purdom E, Wang V, Qi Y, Wilkerson MD, Miller CR, Ding L, Golub T, Mesirov JP, Alexe G, Lawrence M, O'Kelly M, Tamayo P, Weir BA, Gabriel S, Winckler W, Gupta S, Jakkula L, Feiler HS, Hodgson JG, James CD, Sarkaria JN, Brennan C, Kahn A, Spellman PT, Wilson RK, Speed TP, Gray JW, Meyerson M, Getz G, Perou CM, Hayes DN. Integrated genomic analysis identifies clinically relevant subtypes of glioblastoma characterized by abnormalities in PDGFRA, IDH1, EGFR, and NF1. Cancer cell. 2010; 17:98-110.
36. Phillips HS, Kharbanda S, Chen R, Forrest WF, Soriano RH, Wu TD, Misra A, Nigro JM, Colman H, Soroceanu L, Williams PM, Modrusan Z, Feuerstein BG, Aldape K. Molecular subclasses of high-grade glioma predict prognosis, delineate a pattern of disease progression, and resemble stages in neurogenesis. Cancer cell. 2006; 9:157-173.

37. Christiansen JJ, Rajasekaran AK. Reassessing epithelial to mesenchymal transition as a prerequisite for carcinoma invasion and metastasis. Cancer Res. 2006; 66:8319-8326.

38. Brabletz T. To differentiate or not-routes towards metastasis. Nat Rev Cancer. 2012; 12:425-436.

39. Kahlert UD, Maciaczyk D, Doostkam S, Orr BA, Simons B, Bogiel T, Reithmeier T, Prinz M, Schubert J, Niedermann G, Brabletz T, Eberhart CG, Nikkhah G, Maciaczyk J. Activation of canonical WNT/beta-catenin signaling enhances in vitro motility of glioblastoma cells by activation of ZEB1 and other activators of epithelial-to-mesenchymal transition. Cancer Lett. 2012; 325:42-53.

40. Elias MC, Tozer KR, Silber JR, Mikheeva S, Deng M, Morrison RS, Manning TC, Silbergeld DL, Glackin CA, Reh TA, Rostomily RC. TWIST is expressed in human gliomas and promotes invasion. Neoplasia. 2005; 7: 824-837.

41. Han SP, Kim JH, Han ME, Sim HE, Kim KS, Yoon S, Baek SY, Kim BS, Oh SO. SNAI1 is involved in the proliferation and migration of glioblastoma cells. Cell Mol Neurobiol. 2011; 31:489-496.

42. Yang HW, Menon LG, Black PM, Carroll RS, Johnson MD. SNAI2/Slug promotes growth and invasion in human gliomas. BMC cancer. 2010; 10:301.

43. Sunayama J, Matsuda K, Sato A, Tachibana K, Suzuki K, Narita Y, Shibui S, Sakurada K, Kayama T, Tomiyama A, Kitanaka C. Crosstalk between the PI3K/mTOR and MEK/ ERK pathways involved in the maintenance of self-renewal and tumorigenicity of glioblastoma stem-like cells. Stem cells. 2010; 28:1930-1939.

44. Kleber S, Sancho-Martinez I, Wiestler B, Beisel A, Gieffers C, Hill O, Thiemann M, Mueller W, Sykora J, Kuhn A, Schreglmann N, Letellier E, Zuliani C, Klussmann S, Teodorczyk M, Gröne HJ, Ganten TM, Sültmann H, Tüttenberg J, von Deimling A, Regnier-Vigouroux A, Herold-Mende C, Martin-Villalba A. Yes and PI3K bind CD95 to signal invasion of glioblastoma. Cancer cell. 2008; 13:235-248.

45. Park CM, Park MJ, Kwak HJ, Lee HC, Kim MS, Lee SH, Park IC, Rhee $\mathrm{CH}$, Hong SI. Ionizing radiation enhances matrix metalloproteinase-2 secretion and invasion of glioma cells through Src/epidermal growth factor receptormediated p38/Akt and phosphatidylinositol 3-kinase/Akt signaling pathways. Cancer Res. 2006; 66:8511-8519.

46. Lu JT, Zhao WD, He W, Wei W. Hedgehog signaling pathway mediates invasion and metastasis of hepatocellular carcinoma via ERK pathway. Acta Pharmacol Sin. 2012; 33:691-700. 
47. Velpula KK, Rehman AA, Chelluboina B, Dasari VR, Gondi CS, Rao JS, Veeravalli KK. Glioma stem cell invasion through regulation of the interconnected ERK, integrin alpha6 and N-cadherin signaling pathway. Cell Signal. 2012; 24:2076-2084.

48. Guo G, Yao W, Zhang Q, Bo Y. Oleanolic acid suppresses migration and invasion of malignant glioma cells by inactivating MAPK/ERK signaling pathway. PLoS One. 2013; 8:e72079.
49. Song $\mathrm{Y}$, Luo Q, Long $\mathrm{H}, \mathrm{Hu} Z$, Que T, Zhang X, Li Z, Wang G, Yi L, Liu Z, Fang W, Qi S. Alpha-enolase as a potential cancer prognostic marker promotes cell growth, migration, and invasion in glioma. Mol Cancer. 2014; $13: 65$.

50. Kleihues P, Burger PC, Scheithauer BW. The new WHO classification of brain tumours. Brain Pathol. 1993; $3: 255-268$. 